\title{
ANALYSIS OF CUSTOMER FOCUSED STEEL PRODUCT DEVELOPMENT BY USING QUALITY FUNCTION DEPLOYMENT
}

\author{
ABRAHAM MOODY K $\mathbf{1}^{1}$, R R LAL ${ }^{2} \&$ VIJAY PANDEY ${ }^{3}$ \\ 1,2 Department of Mechanical Engineering, AISECT University, Bhopal, Madhya Pradesh, India \\ ${ }^{3}$ Department of Production Engineering, B. I. T., Mesra, Ranchi, Jharkhand, India
}

\section{ABSRACT}

This paper gives a prospective view of QFD methodology and reach to product development. The intention is to enable the customers to initiate and interact with the product development process, which gives a competitive factor by augmenting customer value and strong relation to customers, which increase belief in the company in competitive business. The customer driven product development (CDPD) is found through an explored research design along with global industrial markets and its customer. Using the Tool QFD which translates customer needs into technical requirements, analyzes and assesses the competitor's product parameters, this paper recommends a conceptual model of QFD implementation focussing to establish quality parameters in the steel rolling industry. The customer is involved in all the phases of process development viz. Product planning, design, process planning, operations planning, and forms of a new derived system to the customer. In this paper, the product square bar of hot rolled steel plant has been studied for the ranking of customer requirements and prioritized design. Using this method keeps customer focused reduction in the product development cycle, increases customer satisfaction.

KEYWORDS: Customer Requirements (CR), Technical Requirements (TR), Prioritized Customer Requirements (PCR). Prioritized Technical Requirements (PTR), Customer Competitive Assessment (CCA), Technical Competitive Assessment (TCA) \& House of Quality $(\mathrm{HOQ})$

Received: May 10, 2017; Accepted: Jun 01, 2017; Published: Jun 27, 2017; Paper Id.: IJMPERDAUG20171

\section{INTRODUCTION}

In the course of the most recent two decades, the development of a worldwide economy described by disjoin universal rivalry, separation markets of separating clients, the quickly developing innovative change has constrained new mechanical upheaval. This upheaval has been controlled by the unrivalled quality administration operations of Japanese organizations found by Americans in the 1980s.

Nowadays, huge quantities of organizations speeding their scope of generation and process, driving an exceptional skilled environment, capturing a market relies on request by utilizing normal procedures effectively. Actually item benefits must be raised over the client's desires, removing the advantage from as opposed to trading off them.

Quality Function Deployment is a device for drawing the voices of the client into product improvement, prepare from an origination outline by the manufacturer. QFD uncovers client needs/requirements and interprets them into obliged arrangements to create items to meet these client needs. The voice of the customer is named as Customer Requirements (CR)

The voice of the customer is epitomised in different ways: Direct discourse or meetings, reviews, center 
gatherings, client details, perception, guarantee information, field reports, and so on, this translation of the client needs are then summarized in item arranging network or House of value.

Quality capacity sending is a client driven device in actualizing absolute quality administration. Among large portions of TQM strategies, QFD deciphered client needs and requirements into technical requirements (TR) by coordinating advertising, plan designing, fabricating, and other pertinent elements of an association (Akao, 1990).

\section{METHODOLOGY}

\section{QFD Methodology}

QFD [1] was developed in the standpoint of new product development to create a robust association between customer requirements and the utilities and structures in the intended products, in a systematic and controlled approach [2]. The unique QFD method shelters the invention growth series from the planning stage to actual production using a set of four circumstances relating inputs to outputs [3]. The first condition, called 'House of Quality' (HOQ) interprets customer necessities into product's features [5] and considered as one of the important primary tools used by QFD in maximum studies [14]. Even though authors use many divergences of the HOQ matrix, the field considered 'Voice of the Customer what' is also mentioned to as 'customer's prerequisites' (CR) [6].

QFD solicitations have extended from early solicitations in the automobile, electronics and software sectors of many manufacturing industries and more recently to the service sector, including distance education (Murgatroyd, 1993), incorporation of products and services large-scale social system restructuring and almost every other industry [2]. Due to the growing significance of ecological concerns, current studies have merged ecological and sustainability outlooks into QFD, branded green QFD, Eco-QFD or ([12].

While consumers are at the heart of QFD, more miscellaneous investor groups have recently been measured in the QFD literature [13]. Investors are defined as 'a group or individual who can affect or gets exaggerated by the accomplishment of the organization's intentions'[9]. To define in a simple way, investors are the one who finance their amount of any product by calculating its ROI and profitability [7], [10]. [15], and the same can be said as the perception of investors towards strategic development [10].

Latest studies related to public sector applying QFD with a multi investor perspective do not actually denote the policy expansion. Rather, their emphasis on explicit organizations, projects, or at the widest to well-defined industries. For instance, budget allocation and project selection in the background of homeland security speculation verdicts [8], and the energy security management prototype applied to the Korean natural gas sector [16]. This means that such applications can consider the importance of stakeholders from the organizations, projects or industrial viewpoint. Such approaches do not readily apply in predominant strategy frameworks where policies from many different government departments are measured.

\section{QFD Construction Involves Four Stages: Figure 1}

- $\quad$ Product planning (House of Quality) - interpreting (CR) and desires into TR to satisfy them;

- Product design interpreting TR in key components of value attributes;

- Planning process distinguishing key operations that add to acquiring the key estimations of value qualities; 
- Process control setting up, process control, preparing arrangements to control the whole procedure by considering the client's voice
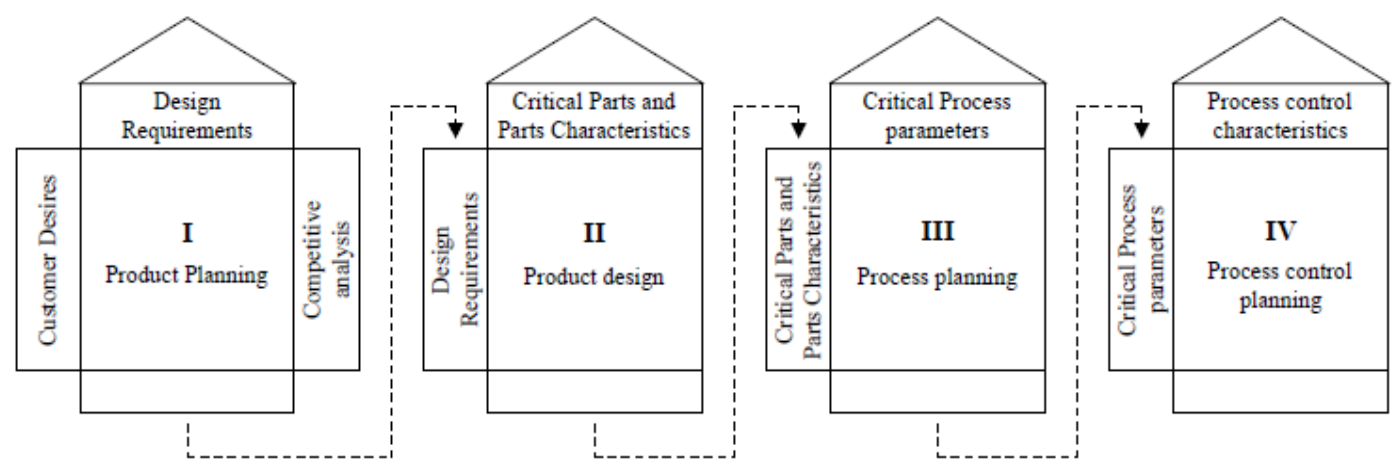

Figure 1: Phase of QFD Process

The Components of Phases of Value (HOQ) Figure 3 Are

- Identifies CR (WHATs) and assesses.

- Competitiveness of service

- Translates CR into Engineering design characteristics (HOW)

- Defines the relationship between (WHAT) and (HOWs)

- Defining relations between various Engineering design and design characteristics

The Method for deciding (WHATs) and (HOWs) is the Focus Group

\section{QFD}

\section{Building a House of Quality}

Authers [4],[17] Dale H. Bester field, Carol Bester field-Michna, Glen H. Bester field, Mary Bester field-Sacre, Hermant Urdhwareshe, Rashmi Urdhwareshe depicted in the book of Total quality Management

\section{Step I: Listing the CR (WHAT's)}

Quality capacity begins with a list of objectives/destinations. This list is known as WHATs that a CR or expects of a particular product.

\section{Step II: List of TC or Design Parameters (HOWs)}

The goal of HOQ is to change the plan of the item to the desire of the customer. These TR make up the roof, second floor of the HOQ. (Figure 3)

\section{Step III: Develop a Relationship Matrix amongst WHATs and HOWs}

In Building the HOQ is to look at the CR and TR and decide their relationship as two dimensional lattice. In this paper the relation between CR and TR as strong relationship (9), medium (3) weak 1 


\section{Step IV: Develop an Interrelationship Matrix between HOWs}

The roof of the HOQ is a correlation matrix is used to identify any relationship between each of the TR is a triangular table attached to TR.

\begin{tabular}{|c|c|c|}
\hline & CUSTOMER REQUIREMENTS & TECHNICAL CHRARECTERSTICS \\
\hline & quality edge & cutting \\
\hline & Quality surface & Heat treatment \\
\hline & Grade of steel & Heating of mill feedstock \\
\hline & Homogenious treatment & Square br rating \\
\hline & Weather conditon protection & Corrosion protection \\
\hline & Geometry Shape & Cotrol of charge \\
\hline & Loading Proceduress & Loading \\
\hline & Basic research of technical characterstics & Scientifc research \\
\hline & Customer Acceptance & Acceptance of product \\
\hline & Speed of realization of customer orders & Cutomer orders \\
\hline
\end{tabular}

Figure 2: Translation of Customer Voices

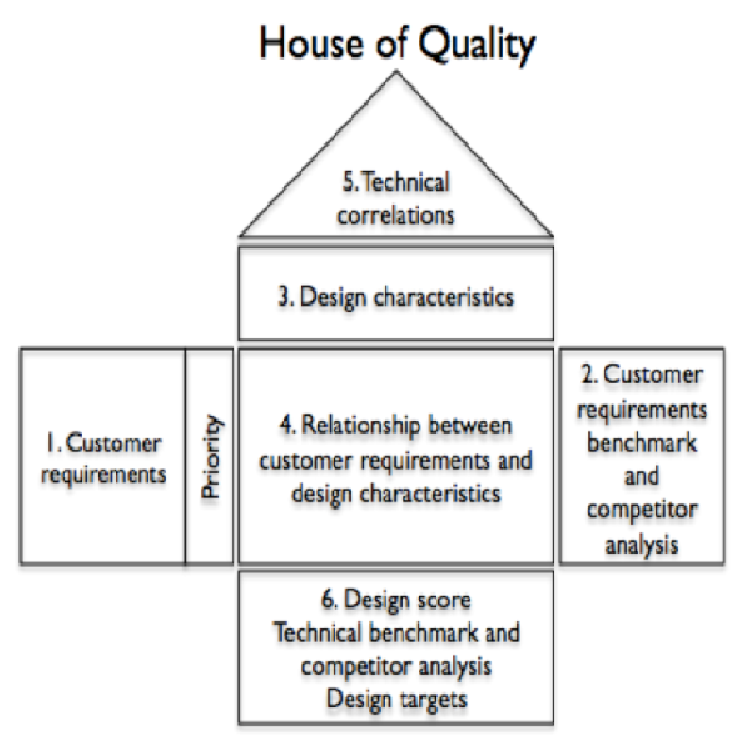

Figure 3: HOQ

Step VI: Develop Prioritized Customer Requirements (PCR) Figure 5

These PCR contain columns for importance to customer, target value, scale-up factor, sale point, and an absolute weight.

- $\quad$ Importance: (CR) ranking 1 to 10.

- $\quad$ Target Value: Customer competitive assessment (CCA) scale 1 to 5. 


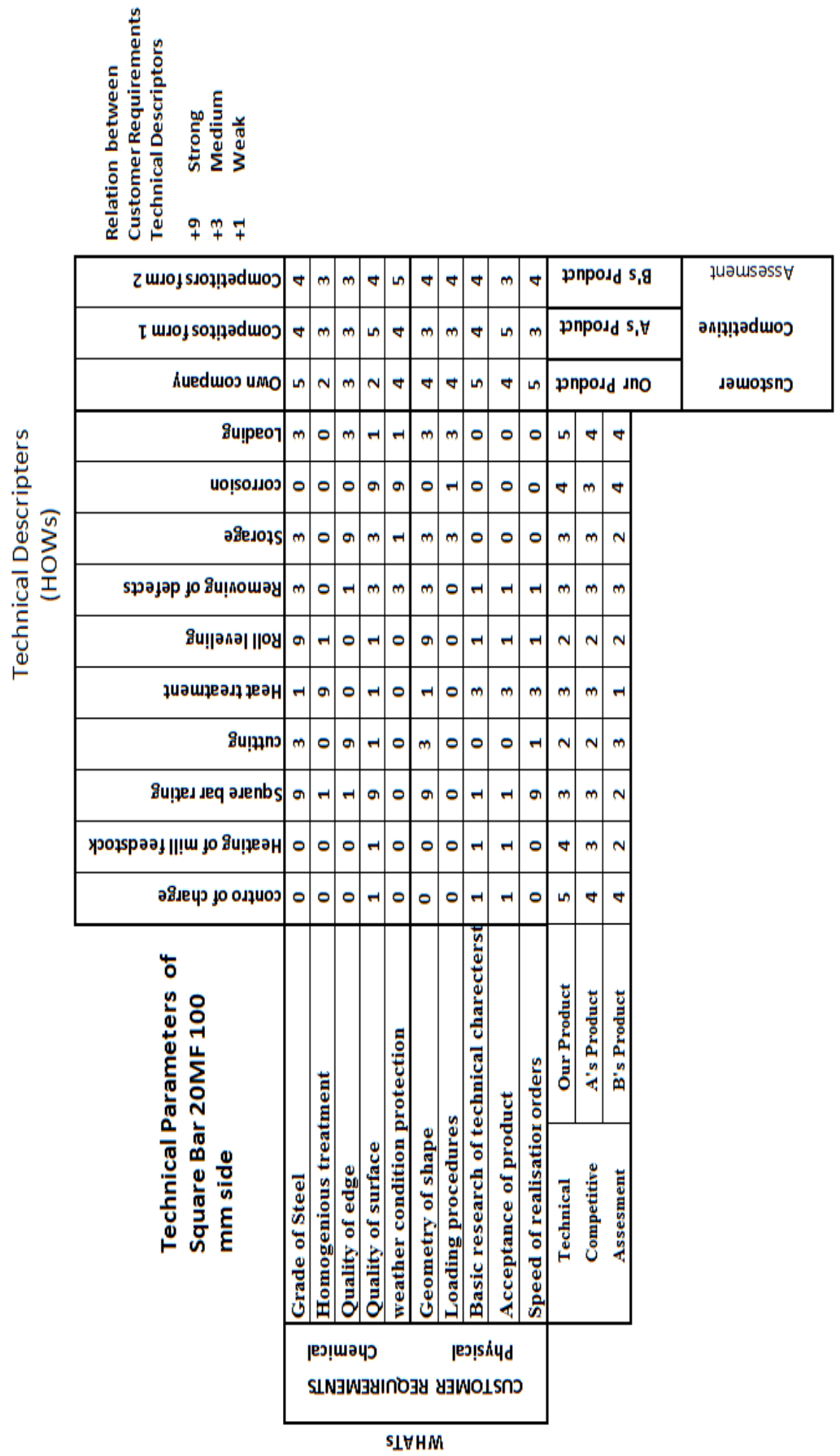

Figure 4: HOQ with CCA

- Scale-up factor: Is the ratio of target value of the product rating in CCA.

- Sale Point: determined by identifying CR scale 1 to 2 


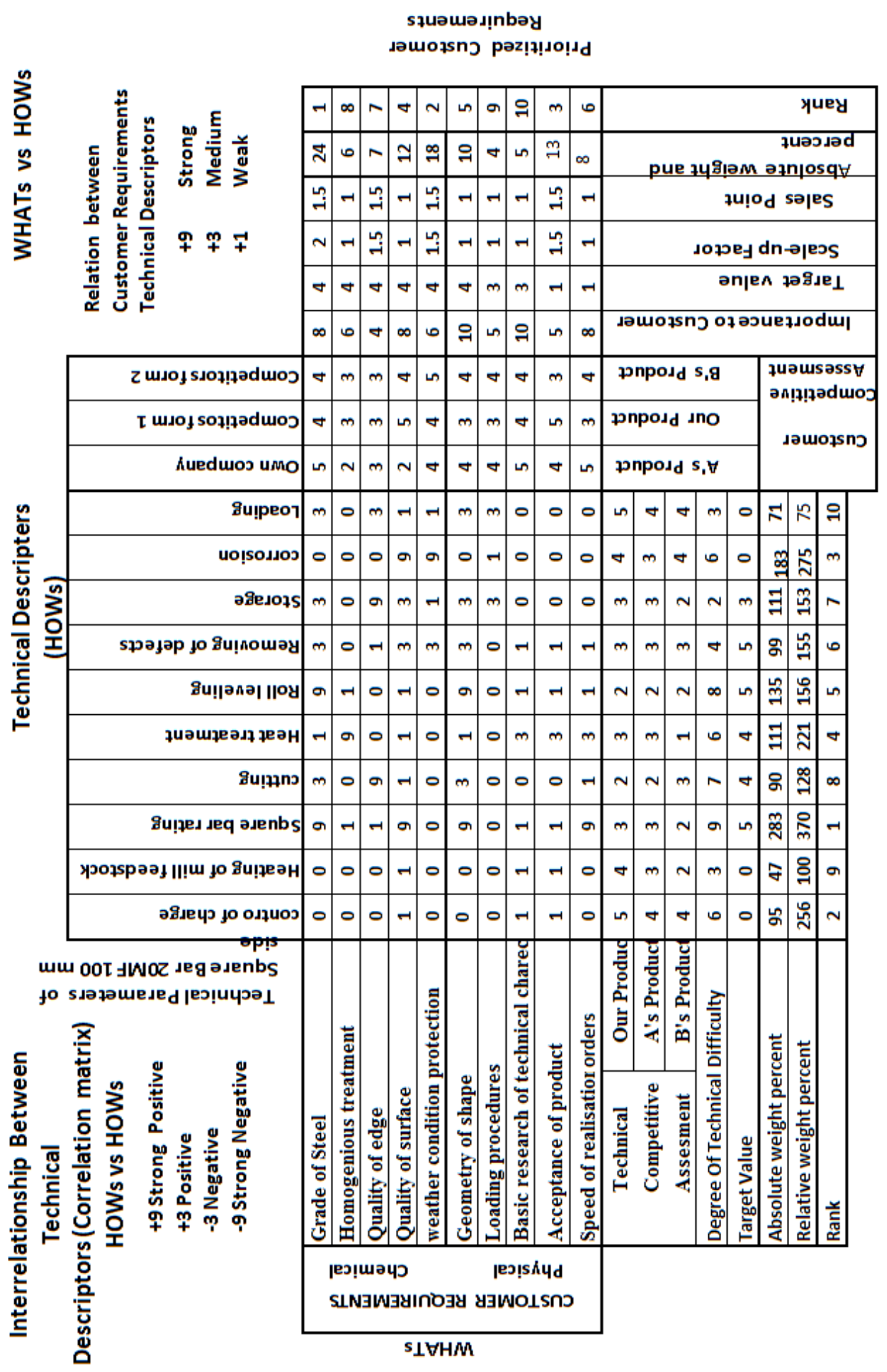

Figure 5: HOQ-PCR \& TR

Re-arranging the Ranking of the Customer Requirements and Engineering Characteristics. 
1 Re-Arranged Rank of Requirements Customer as per Absolute weight

\begin{tabular}{|c|l|c|}
\hline Rank & \multicolumn{1}{|c|}{ Customer Requirement } & S.No \\
\hline 1 & Grade of Steel & 1 \\
\hline 2 & Weather Conditon Protection & 5 \\
\hline 3 & Acceptance of Product & 9 \\
\hline 7 & Quality Surface & 4 \\
\hline 5 & Geometry of Shape & 6 \\
\hline 6 & Speed of realization & 10 \\
\hline 7 & Quality of Edge & 3 \\
\hline 8 & Homogenios Treatment & 2 \\
\hline 9 & Loading Proceedures & 7 \\
\hline 10 & Basic research of technical characteristics & 8 \\
\hline
\end{tabular}

Fig, 6

2 Re-Arranged Rank of Customer Requirements As Per Importance Rating

\begin{tabular}{|c|l|c|}
\hline Rank & \multicolumn{1}{|c|}{ Customer Requirement } & S.No \\
\hline 1 & Geometry of Shape & 6 \\
\hline 2 & Basic research of technical characteristics & 8 \\
\hline 3 & Speed of realisation of orders & 10 \\
\hline 4 & Grade of Steel & 1 \\
\hline 5 & Quality of Surface & 4 \\
\hline 6 & Weather Condition Protection & 5 \\
\hline 7 & Homogenious Treatment & 2 \\
\hline 8 & Acceptance of Product & 9 \\
\hline 9 & Loading Proceedures & 7 \\
\hline 10 & Quality of Edge & 3 \\
\hline
\end{tabular}

Fig. 7

3 Re-arranged Rank of Engineering Characteristis as per Ralative Weight

\begin{tabular}{|c|l|c|}
\hline Rank & Engineering Characteristic & S.No \\
\hline 1 & Square Bar Rating & 3 \\
\hline 2 & Control of charge & 1 \\
\hline 3 & Corrosion & 9 \\
\hline 4 & Heat Treatment & 5 \\
\hline 5 & Rolling Level & 6 \\
\hline 6 & Removing of Defects & 7 \\
\hline 7 & Storage & 8 \\
\hline 8 & Cutting & 4 \\
\hline 9 & Heating of mill feedstock & 2 \\
\hline 10 & Loading & 10 \\
\hline
\end{tabular}

Fig. 8 


\section{ANALYSIS}

As indicated by [18] quality proceeds with change of the creative process in part of utilization

Investigation HOQ for hot rolled steel square bar has been exhibited (Figure.3). The working of The House of Quality covered the following stages:

Stage I: The Demands and expectations of customer have been set up.

Stage II: The importance of demands of customers has been grouped. And further more CR is grouped into physical and Chemical for better location of the category they come under has been set up.

Stage III: The scale of the significance of own activity at the customer with his requirements has been analyzed.

Stage IV: Fulfilled Demands of customers have been allotted to relating parameters of the product. Sufficient information is acquired - customer's anticipation and by product acknowledgement

Stage V to VII: Degree of technical difficulty, the potential outcomes of accomplishing the point, the troubles in specialized acknowledgment has been characterized.

Stage VIII: The dependence field between stage I and stage II.

Stage IX: Comparison between company's product and competitor's product - in view of customer's expectation in (Figure 4)

Stage X: The investigation of estimation accomplished by the customer.

Stage XI: Comparison between company's product and competitor's product - in view of technical parameters (figure 4)

Stage XII: The mutual dependence field between technical parameters of hot rolled steel.

Stage XIII: The PCA (Target value, Scale-up factor, Sales point, absolute weight and percent) are estimated (Figure 5)

\section{CONCLUSIONS}

Elaboration and implementation of indeed effective methods of measurement of the satisfaction of the customer are of great importance, being very complicated at the same time.

In the investigation [21] of CR identified with steel square bar, the QFD strategy has been used for hot rolled steel square side:100 mm and length 1000-2500 mm with grade of 20MF concurring the relations between the CR and relations at top of HOQ are numerically ascertained and have affect on Internal outside elements of the company. [19] The Absolute weight for each TR is determined by taking the dot product of the column in the relationship matrix and column weight of importance to the customer.

Figure 6 indicates the Sorted rank of customer Requirements as per Absolute weight percent.

Figure 7 indicates the Re-arranged Rank as per Customer Requirements as per Importance rating.

Figure 8 indicates that Rearranged Rank of Engineering Characteristics as per Relative weight percent. 


\section{REFERENCES}

1. Y. Akao, New product development and quality assurance deployment system Stand. Qual. Control, 25 (1972), pp. 243-246

2. Chan, L. K., and M. L. Wu. 2005. A systematic approach to quality function deployment with a full illustrative example. Omega 33: 119-139

3. Eldin, N. (2002): A Promising Planning Tool: Quality Function Deployment, Cost Engineering Vol. 44 (3),

4. Dale H. Bester field, Carol Bester field-Michna, Glen H. Bester field, Mary Bester field-Sacre, Hermant Urdhwareshe, Rashmi Urdhwareshe "Total Quality Management", Pearson edition (Revised Edition 2011)

5. Linda J. Morris John S. Morris 'Introducing Quality Function Deployment in the Marketing Classroom' Journal of Marketing Education, First Published August 1, 1999

6. Yahia Zare, Mehrjerdi "Quality function deployment and its extensions", International Journal of Quality \& Reliability Management, (2010) Vol. 27 Iss: 6, pp.616 - 640

7. F., Pereira Z. L., "Improving the use of QFD with Axiomatic Design", Concurrent Engineering... on Axiornatir Deiign, I CADZOO9, Campus de Caparica, NIarch 25-27, 2009.

8. H. M. Fallah, F. H. Murphy, E. A. Stohr "A Methodology for improving the investment portfolio management process for the homeland security department using quality function deployment" Public Budg. Finance. 30 (2010), pp. 1-2

9. R. E. Freeman Strategic Management: a Stakeholder Approach, Pitman, Boston, MA (1984).

10. Robert M. Gerst." QFD in large-scale social system redesign”, International Journal of Quality \& Reliability Management, Vol.21 No.9, 2004, pp.959-972

11. Lai-Kow Chan, Ming-Lu Wu, Quality Function Deployment: A Literature Review, European journal of Operation Research, $P$ 143(3):463-497 · December 2002

12. G. Büyüközkan, Ç. Berkol Designing a sustainable supply chain using an integrated analytic network process and goal programming approach in quality function deployment Expert Syst. Appl., (2011).

13. P. K. Dey, A. Bhattacharya, W. Ho Strategic supplier performance evaluation: a case-based action research of a UK manufacturing organisation Int. J. Prod. Econ., 166 (2015), pp. 192-214

14. J. R. Hauser, D. Clausing 'The house of quality' Harv. Bus. Rev., 66 (1988), p. 3

15. Driessen and Hilebrand, 2013 P. H. Driessen, B. Hildebrand Integrating multiple stakeholder issues in new product development: an exploration J. Prod. Innov. Manag, 30 (2) (2013), pp. 364-379

16. Juneseuk Shin, Wan-Seon Shin Changyong Lee "An energy security management model using quality function deployment and system dynamics” August 2014 with 283 Reads DOI: 10.1016/j.enpol.2012.10.074 26.92 · Sungkyunkwan University 23.15 . Ulsan National Institute of Science and Tech

17. Dr. Mizuno, professor emeritus of the Tokyo Institute of Technology. The first application of QFD was at Mitsubishi, Heavy Industries Ltd., in Kobe Shipyard, Japan.

18. M. Dudek-Burlikowska, D. Szewieczek, "Quality estimation methods used in Product life cycle”, Journal of Achievements in Materials and Manufacturing Engineering volume 28, issue May 2008.

19. Abraham Moody K, Vijay Panday, R R Lal," Investigation of Customer Focussed Steel Plant Product With Quality Function Deployment” International Journal of Mechanical Engineering and Technology 8(4),2017, pp. 19-25 
20. Abraham Moody K, R. R Lal and Vijay Pandey, Analysis of Customer Oriented Product Development with Quality Function Deployment, International Journal of Mechanical Engineering and Technology, 8(5), 2017, pp. 270-279.

21. Abraham Moody K, Vijay Pandey and R. R Lal, Analysis of Customer Focussed Product Development by using Quality Function Deployment, Proceeding of International Conference: ARIMPIE-2017, ELK Asia pacific journals-Special Issue, Vol (3) 2017, pp. 341-346. 